\title{
Turkish Islamism in the Post-Gezi Park Era
}

\author{
Halil Ibrahim Yenigun
}

\begin{abstract}
The Gezi Park protests have stirred serious controversy both inside and outside Turkey on the JDP's ruling style and ideology. By drawing on el-Affendi's distinction between the Medina and Damascus models, I discuss the Islamist opposition to Erdoğan during the Gezi events. I argue that notwithstanding his recent Islamization policies, Erdoğan's JDP is a conservative party that caters to Muslim nationalism while a new Islamism as an ethico-political ideal has been in the making by the praxis of the new Islamist youth.
\end{abstract}

Most accounts that have suggested the Turkish conservative-democratic or "post-Islamist" model as an operational formula for the Muslim world have recently had to be revisited. It is not because the July coup in Egypt and the turmoil and civil war in the rest of the Arab region have foiled the hopes that democratization was indeed underway. But in fact, the Turkish case itself has come under scrutiny due to the outbreak of popular discontent in Istanbul's Taksim Gezi Park during May-June 2013. Indeed, despite his mixed record and continual policy oscillations in the immediate aftermath of his third victory in the 2011 general elections, many Turkish citizens of various ideological backgrounds were still supportive of Prime Minister Tayyip Erdoğan and most of his ruling JDP's (Justice and Development Party) social and political reforms. A sizeable number of his own party's religious electorate, however, were already quite critical of him for not dealing with the nepotism and corruption among party officials, the extravagant lifestyles of the JDP nouveau riche who owe their wealth to at least questionable government contracts, blatant capitalistic relations in religiously owned companies that perpetuated insecure and unsafe work conditions for low-income employees, and increasing reports of consistently covered-up sexual harassment and illegal affairs indulged in by high-level JDP bureaucrats.

Halil Ibrahim Yenigün is a faculty member at Istanbul Commerce University, Department of International Relations. He holds a Ph.D. from the University of Virginia's political theory program. His research fields include political ontology, political theology, radical democracy, and contemporary Muslim political thought. He also served as the managing editor of the AJISS during 2006-10. 
The entire political scene changed in June. Most of the secular and liberal leftist JDP supporters have now become Erdoğan's irreversibly staunch opponents. But most of the party's religious constituency who used to vote for it, for want of better options, have suddenly become his adamant supporters. They will now immediately go berserk if one simply voices a critical opinion of him and accuse him or her of treason to religious ideals and undermining the wellbeing of the country's religious people. Before the JDP, Turkish people were ideologically polarized and ethnically divided, yet non-Kemalist identities were suppressed and people were opaque. Now identities have become crystal clear, but we are once again polarized; only this time it is determined by one's position toward the Gezi Park protests and Erdoğan himself.

So what happened to Turkey and its once deeply admired conservativedemocratic or post-Islamist model? Is the country really going through a new authoritarian period, or is it just that the Kemalist secularists, having failed to keep Turkish people in a forcible secularist line, formed a new front of opposition? Then why have we not seen any serious protests against the hijabi MPs who entered Parliament without going through what Merve Kavakçı faced fourteen years ago ${ }^{1}$ Are we witnessing new political cleavages for a country that had been sharply divided along the religious vs. secularist line? Or have the old politics and Erdoğan's hidden Islamist agenda only come to the fore after the military tutelage over civilian politics ended?

In fact, there were already signs of serious discontent among some of the JDP's religious, Kurdish, and secular liberal supporters some time after the beginning of Erdoğan's third term. As the September 2010 referendum finally removed the grip of the Kemalist secularist state elite, many expected Erdoğan to launch a courageous project to draft a first-time civilian constitution that would bring Kurdish, Islamist, liberal, and other secular elements to the table. There was an aura of optimism among the Kurdish constituency, who accorded Erdoğan a high degree of credibility. But things took an unexpected turn as the prime minister changed his stance toward the Kurdish movement. Ankara cracked down on the Kurdish opposition with egregious police brutality and jailed some pro-Kurdish intellectuals and academics without much regard for due process. ${ }^{2}$ Student opposition was ruthlessly suppressed on university campuses by the excessive use of tear gas and force. Ergenekon trials, which came as a big blow against the Turkish deep-state, were tarnished by serious allegations of violations of due process and unfair trials. Environmental opposition grew as Erdoğan's ambitious development projects took a high toll on the environment, especially due to hydro plants that threaten the natural habitat in the Black Sea region. ${ }^{3}$ But the worst happened on December 28, 2011, when, 
in its decision to fight the PKK by draconian measures, Ankara bombed thirtyseven civilians from the village of Ortasu (Kurdish original: Roboski) in the Kurdish township of Uludere, mistaking them for PKK militants.

This was the turning point for many, because Erdoğan neither responded to the public demands for a thorough investigation and revelation of the responsible party, nor did he ever issue a formal apology. It was also significant that the domestic media failed to report such an important incident and that some Turks first heard of it through the international news agencies. This development came amidst claims of increasing government pressure on the freedom of press. Those who pursued the Roboski massacre in the media were upbraided and censored. The most significant incident in this regard was when Ali Akel, the Washington, DC reporter for the pro-government newspaper Yeni Şafak, was sacked after he demanded that Erdoğan, his long-time friend, apologize to the victims. ${ }^{4}$ Erdoğan took no responsibility for Akel's firing and maintained that he was not the one to blame.

Perceptions and worries of increasing authoritarianism were exacerbated as new incidents unfolded. On August 9, 2012, the Islamist human rights association Mazlum-Der organized an iftär inside the courtyard of Istanbul's Fatih Mosque to demand justice for Roboski/Uludere. It was raided by three men carrying a gun, a baseball bat, and a large slicing knife. They chanted ultranationalist slogans and threatened the participants, largely independent Islamist youth groups, with their weapons. As Mazlum-Der followed up on the incident, it turned out the men were all ex-cons and likely on the police department's payroll. This was probably the first known incident of the use of paramilitary thugs (resembling Egypt's baltageya) in the Erdoğan era, especially against the Islamist youth, for the JDP had not been known for such deep-state operations.

The new Islamist youth, who became even more critical of the JDP's neoliberal economic policies and increasing pressure on independent groups, also endured police brutality during the May Day of 2013. ${ }^{5}$ The JDP government, recognized as the first one to allow May Day rallies in Taksim Square after a decades-long ban, now prohibited it on the ground of ongoing renovation work in the area. The socialist groups, which insisted on their right to rally in the symbolic square, were joined by the newly formed Islamist and anti-capitalist groups. The ensuing police brutality caused a public uproar and Dilan Alp, a high school student hit on the head by a tear-gas canister, was perhaps a foreshadowing of what would happen at the end of the month. ${ }^{6}$

The JDP's urban redevelopment plans had already come under the scrutiny of several urban and environmental activist groups that were raising 
public awareness about the neo-liberal urban development model and the human cost of the gentrification processes involved. These efforts, however, remained quite scattered and marginal even though more and more urban youth continued to participate after each event. ${ }^{7}$

The prime minister's plans to replace one of the Taksim Gezi Park area's very few green areas with a shopping mall and possibly a residence gave many discontented people the perfect chance to vent their frustration all at once. When the security forces roughly evicted people who were conducting a peaceful sit-in at the park by burning the tents around 5:00 am on the morning of May 28 and tear gassing the sleeping environmentalists, the public outrage drew thousands to Taksim Square for several days. ${ }^{8}$ The rest of the story was widely covered by the major international news outlets ... well, maybe too much. While it spread to rest of the country in the form of mass protests and clashes with the police, an Occupy-like movement was born in Gezi Park after the police withdrawal on June 1 with its barricades, camps with thousands of protesters in commune-like tents, a make-shift "protester" library, food distribution, and musical and dance performances. After the riot police cleared the Gezi Park camp on June 15, the protests turned into public forums in a variety of public parks all over Turkey.

The scene was not all blissful when the country-wide protests are considered, though, for both sides engaged in many acts of violence. The excessive use of tear gas and water cannons eventually led to thousands of injuries, loss of sight, and five deaths among the protesters. An Adana police chief also died as he fell from a bridge while supervising the riot police. ${ }^{9}$ The protests' timeline and its many dimensions can be thoroughly followed via Wikipedia's account of the events. ${ }^{10}$ Nonetheless, certain highlights are important for my account:

- These events, initially led by environmentalist groups, quickly evolved into a general protest of the ongoing police brutality against peaceful protesters and, in general, Erdoğan paternalistic moralizing attitude and inflammatory language toward the citizens, especially the secular elements. ${ }^{11}$ At first, these protests did not represent the usual secularist vs. religious cleavage that characterized the 2007 protests: Kemalists vs. the possibility of a hijabi first lady. However, as the protests escalated, more Kemalist constituencies joined along with some of the violent ultraleftist organizations and became more visible in the nationwide protests. At the end of the protests, significant damage had been done to public property, which was widely emphasized to prove that the protesters were destructive. 
- Even more significantly, as events unfolded and the ideological dimension became stronger, an alarming extent of harassment against hijabi women all over the country were recorded; these did not, however, extend to Gezi Park. Overall, the basic contenders over the nature of the protests were the liberal seculars, who were more supportive of Kurdish and religious demands, as opposed to the traditional Kemalist secularists, who wanted to retain Kemalism's ultra-secularist policies. Until the very end, participants in this intra-secular struggle did their best to stamp this biggest protest of the JDP era with their own mark. Nonetheless, Gezi Park itself remained ideologically diverse and not dominated by any party or organization. This was also a first-time experience for many Kemalists who had been ideologically secluded until that time. Overall, the core group at the protest's epicenter was - and remained - a diverse coalition until the end. ${ }^{12}$

- As more Kemalists joined the protests, the prime minister preferred to use increasingly divisive language to defend his draconian anti-protest measures and controversial policies by citing his "mandate." Erdoğan's uncompromising stance, coupled by the growing participation of Kemalist masses targeting Erdoğan as a dictator, reinvigorated Turkey's long-standing ideological secularist vs. religious cleavage. Reports of the harassment of hijabi women seemed to play right into his hands, for he emerged as the religious constituency's savior at the expense of extreme societal polarization. Pro-government news sources and writers persistently tried to portray the protests as just another instance of Kemalist intolerance against the democratic will and religious expression composed mainly of the major Kemalist party (the RPP), although many surveys proved that it was never the preferred party of the majority of the protesters. ${ }^{13}$ Even the youth dismissed its opportunistic efforts to assert ownership. ${ }^{14}$

- The Gezi protests radically transformed the use of social media in Turkey. As the regular news channels failed to provide timely and accurate reports, the viewers relied heavily on social media, which then became an arena of verbal attacks, libel, and disinformation by both the pro- and anti-Erdoğan camps. Since then, almost every policy issue in Turkey has turned into major controversy and hit the trending topic on Twitter. Erdoğan himself, who used to dismiss social media, finally decided to employ a huge army of Twitter users to overwhelm his critics and accusers. 
- Conspiracy claims formed a large part of the pro-government camp's campaign against the Gezi protests. On different occasions even high level government officials blamed the Serbian civil society organization Otpor!, interest-rate lobbies, and American neo-cons led by the American Enterprise Institute for planning to stage the protests months earlier. ${ }^{15}$ The foreign news agencies' extraordinary interest, which included hours of live coverage, led many JDP supporters to believe such claims. Still, no foreign involvement before the events erupted has been substantiated so far. ${ }^{16}$

- Two important incidents played a key role in the attitude of the religious public: There was a report that a group of protestors had beaten a hijabi woman in front of her baby in the Kabataş area. The family asked that this event go unreported for several days. But the prime minister leaked it first to the public through the pro-government Yeni S Safak reporter Abdulkadir Selvi and Star reporter Elif Çakır. ${ }^{17}$ Immediately afterward, this incident became the all-time hot topic for Erdoğan, who cried "they attacked my hijabi sister!" over and over again in his public speeches. The other incident took place when a group of protesters, many of them injured, sought refuge in the Valide Sultan Mosque of Dolmabahçe area. They entered without taking off their shoes as the riot police were pepper gassing the whole area. The pro-government news portals alleged that the protesters drank alcohol and even had sex in the mosque in a deliberate attempt to deconsecrate it. Erdoğan loudly proclaimed for several months that "they entered the mosque with their shoes on!" and "they drank [alcohol] in the mosque!" So far, these allegations remain unproven. Moreover, the mosque's muezzin denied such claims and was subsequently sent to a remote village mosque by the government. ${ }^{18}$

- Notwithstanding such polarizing tendencies, the most significant novelty of the Gezi protests was the visibility of the Islamist youth groups and religiously motivated opposition to the AKP anti-protest policies. They played the catalyzing role as regards Turkey's deeply polarized religious and secular elements. The sensational presence of "anti-capitalist Muslims" and their successful effort to celebrate Mi'raj night at Gezi Park worked against Erdoğan and the pro-government media's attempt to portray the protests as anti-Islamic. Their "Earth Table" during Ramadan, where the whole Istiklal Street of Taksim turned into an iftār table, brought together secular and religious masses for iftār. Erdoğan's depiction of the protesters as a monolithically anti-hijabi group was challenged by hijabi 
women themselves, who had come together in the recently formed "Muslims against the Violence against Women Initiative." During their march from Kabataş to Gezi Park that included many seculars, they read a declaration that condemned the attack and criticized Ankara for revealing the mother's identity as well as using this attack for political gains. ${ }^{19}$

- The most astounding move came from the Labor and Justice Coalition, an alliance of Islamist and socialist youth, which organized a meeting at Mazlum-Der and wrote a declaration that was signed by some of Turkey's leading Islamist thinkers, writers, and activists - including prominent Islamist writer Ali Bulaç. ${ }^{20}$ Viewed as a grave challenge to the pro-Ankara religious circles, it was harshly mocked by the pro-government news portals and websites as "The Teenager Declaration of the Intelligentia" and "Here are the Islamists who back the oligarchy." 21 The declaration noted:

We, as Muslims, have not forgotten how media abused the whole country, and sullied the innocent fifteen years ago. Today, the conservative and mainstream media is using the same language to terrorize a certain part of the population - what has changed then? Did we forget what police forces have done to our kids? Why should police be rightful in persecuting others who are not like us? Is not justice a divine command that has to be kept alive against every form of hatred?

- This critique led to serious diatribes against the signatories in the social media arena and incited harsh responses by several columnists. While Enver Gülşen characterized it as an expression of "sterile Muslimness," 22 Rasim Özdenören, a renowned Islamist writer turned government supporter, called it "an interesting case of false consciousness." Gülşen, in a quite Schmittean move, maintained that "the ethical character of a human being is his ability to make decisions under extraordinary circumstances. Saying 'neither/nor' might give us comfort in the sterile compartment we build for ourselves but that sterile compartment, it must not be forgotten, will not bear the unrelenting pressure of the conscience." Özdenören, on the other hand, claimed that "this government has been established de facto and de jure based on the rules prescribed by the 1982 constitution. It is, therefore, a blatant case of false consciousness to expect from it the behavior that would reflect the ethics of a Muslim." ${ }^{23}$ As he continued with the same topic in his next column, he made an interesting comparison that was worth noting: This Islamic challenge against Erdoğan's rule was similar to the challenge of Mehmed Akif (1873-1936), the renowned pioneer of Turkish Islamism and follower of Afghani (1838-97), against Sultan Abdulhamid II's despotism. 
At this point, I would like to present the gist of this controversy. Gülşen and Özdenören are quite right to identify the Islamists' anti-government motive as an "ethical" one (i.e., based on considerations of justice). It is worth noting that both authors use Marxist jargon while objecting to the Islamists' "ideological" outlook and "false consciousness." This suggests that they see the real struggle not as ideational (ethical), but rather as one referring to "material conditions" (purely political). Along the same lines, the analogy to the early twentieth-century major conflict between Turkey's Islamists and Abdulhamid's authoritarian rule is quite correct; in fact, the conflict is between two visions of the "political."

I would like to back up a little bit to clarify this point. The JDP was founded by an ex-Islamist group that parted ways with the utopian form of Islamism that characterized Necmettin Erbakan's (1926-2011) Welfare Party (WP). Its foundation took place in a defeatist mood vis-à-vis the secularist system during an onslaught against all sorts of public expressions of Islam. The best expression of Erdoğan's frustration with Islamism was spelled out during an encounter with an Islamist writer in 2001. When his increasing control over the Islamist newspaper Yeni Şafak in 2001 raised concerns on the part of its Islamist writers who wanted to retain its editorial autonomy, they sought to reconcile their differences. However, the meeting turned into a bitter argument during which Erdoğan did not hide his feelings: "What good did Islamism do for us?" ${ }^{24}$ Around the same time he would also remark that he would not take seriously anyone who spoke of a "shariah state." ${ }^{25}$ This ideological shift toward what Erdoğan himself called "conservative democracy" is, in my belief, key to understanding the ideological conflict that crystallized during the Gezi Park protests.

Perhaps what these protests have revealed most is the difference between Erdoğan's and the Islamists' vision of Islam as regards politics. Asef Bayat's distinction between Islamism and post-Islamism has been widely used to formulate the shift. In fact, post-Islamism seems to be a reasonable characterization for a good part of the JDP's eleven-year rule. ${ }^{26}$ However, in Bayat's understanding, post-Islamism is the attempt to transcend Islamism by emphasizing rights, plurality, and historicity and to orient itself toward the future. ${ }^{27}$ In many ways Erdoğan's Islamization policies, where he declared were designed to raise "religious generations" and intervene in co-ed housing on the ground that they contradicted the JDP's conservative democratic ideology, might look like a return of the Welfare Party. Are Erdoğan's clear threats against secular lifestyles in Turkey really an indication of a return to his Islamist roots, which would prove the secularist suspicions that he has had a 
hidden agenda all along?28 In my opinion, however, what might be required here is a different conceptualization.

One might be justified for holding the impression that Erdoğan's domestic Islamization policies, as well as his pro-Islamist policies in the Arab world, especially his staunch support for Palestine's Hamas, Egypt's Muslim Brotherhood, and the Free Syrian Army, are clear evidence of his Islamism. But there are several other ways to formulate this, for instance, by making an analytical distinction between Muslim nationalism/Muslimism ${ }^{29}$ vs. Islamism, or what Abdelwahab el-Affendi calls the Damascus model (realist-pragmatic school) vs. the Medina model (idealist school). ${ }^{30} \mathrm{He}$ traces the idealist school back to Ali, while Mu'awiyah is the architect of the Damascus model. The idealist model only sporadically manifested itself during the reigns of Umar, Ali, and Umar ibn Abd al-Aziz (r. 717-20). On the other hand, the Damascus model was characterized by its disregard for puritanism and its affirmation of realpolitik. With fewer demands and more rewards, it was destined to be more stable. In this framework, el-Affendi sees the recurrent ethicalist and puritan revolts, including those of Imam Hussain, the Shi' ${ }^{\circ}$ ah, the Khawarij, and Abdullah ibn Zubayr as precursors of the Islamists. ${ }^{31}$

While I do not appropriate all aspects of his distinction, I maintain that it grasps the defining element of Islamism as opposed to the other form of political Islam: Muslimism or Muslim nationalism. When religious Muslims were subjugated by the Muslim world's secularist elite, the language of Islamism appeared to be "the language of self-assertion to mobilize those ... who felt marginalized by the dominant economic, political, or cultural processes in their societies." 32 However, this language might have harbored both a quest for "justice" (an ethical aspiration) and a quest for "power" (a political aspiration) without any need or pressure to differentiate between the two. This explains why, in Islamist politics, power-seekers could always have existed side-by-side with ethically motivated idealists as well as puritans in whose political theologies politics was meant to be the pure reflection of faith commitments.

By reappropriating el-Affendi's terminology of the Damascus and Medina models, I would like to articulate Islamism as a faith-based ethico-political project drawing on the Medina model as opposed to "Muslim nationalism" or "Muslimism." The latter ones here stand out as a quest for Muslim domination drawing on the Damascus model. Via this analytical distinction, we can grasp the source of the conflict between Abdulhamid II and the Turkish Islamists, or even between Abdulhamid II and al-Afghani for that matter. Islamist politics in various countries have manifested several instances of abuse of power, a dogmatic political perspective, and so on over the decades. How- 
ever, I contend that the Islamist intellectual tradition has, for the most part, retained a strong ethical thrust with its orientation toward human freedom, justice, world peace, and humanity's overall good. ${ }^{33}$ Early Turkish Islamists were determined opponents of Abdulhamid II because they believed that bad government was one reason for the Muslim world's decline. The Qur'an enjoined consultation (shüra) for Muslims, for it would elevate human dignity to its proper status and would be best realized through a constitutional regime. Their thinking did not involve strategic rationality at the expense of ethical considerations, as one could discern in the sultan's mentality.

The Turkish Islamists of Erdoğan's generation, whose understanding of Islamism took shape during the 1970 s, were pretty much opposed to his ideological shift during the late 1990s. Theirs was a rather utopian understanding based on pure principles, one that had little to offer in terms of practical politics. After he rejected this understanding and right after his rise to power, Erdoğan faced his first predicament: Washington's demand that Turkey pass a motion to allow the stationing of American troops on Turkish soil for the occupation of Iraq in early 2003. During such a critical time, Erdoğan's demand that his deputies support the motion caused the Islamists to reject any compromise and subject him to harsh criticism. They sent "bloody" shirts to JDP's headquarters to symbolize the blood of the would-be war victims and warned its deputies as well as Erdoğan himself: "Do not be servants to the Big Satan, but be servants of God!'34 This was happening while the military tutelage over the party's civilian rule was still in full force and their opposition was undermining Erdoğan's hard slog toward establishing his government's authority. So what happened during the ten years of JDP rule that caused the older generation, which had once been more radical antagonists of Erdoğan, to berate so harshly the new Islamist youth's opposition to the all-powerful JDP's police brutality?

Erdoğan never called himself an Islamist after he broke with them around the early 2000s; however, as he strengthened his rule he secured their support by providing several opportunities to them: high-level offices, government contracts to Islamist businessmen, the transfer of a generous amount of surplus money to Islamist or religious NGOs, and other perks. Over the years, he also assumed the role of protecting Muslim interests both domestically and worldwide in his foreign policy agenda. By such moves, the JDP emerged as the embodiment of Islamist goals, the telos of Turkish Islamism, so to say, in the eyes of most Islamists. Erdoğan's strategy to co-opt the Islamists even included deploying the most radical of them to achieve his goal of toppling Syria's Bashar al-Assad while the Islamists pursued their agenda of coalescing 
with the Free Syrian Army. It is against this background that the ex-Islamist constituency's current submissiveness and adamant support for Erdoğan must be interpreted.

In short, what was at stake for most of those once-radical Islamists were the opportunities opened up by the conservative JDP government as well as the political gains for the religious public. As a result, Erdoğan's once-harshest critics acted as his most adamant defenders against the new Islamist youth. While they were among the first to ally themselves with the socialists during Erdoğan's intended support for the United States' aggression in Iraq, they attacked their own youth for sympathizing with the victims of police brutality.

This story of political and ideological transformation is quite telling in many respects. But most significantly, it has provided a concrete case that allows one to distinguish the JDP, along with its ex-Islamist supporters, from the new Islamism. Insofar as the JDP has embodied the quest for Muslim power without due regard for the ethical demands, Islamism has to be delineated as an ethico-political ideal intrinsic in the praxis of the Muslim youth who have demanded justice in Roboski or supported the victims of police brutality. One might also argue that as the puritan Islamists turned into strategic thinkers in their effort to maximize Muslim interests in any situation, other Muslims took on the mission of vicegerency to be witnesses to justice and to speak truth to power. This was perhaps the gist of Dabashi's argument when he said: "Islam is triumphant at the moment of its insurrection, defeated at the moment of its success ... Because it has historically spoken the truth to power, it cannot be in power, for it then robs itself of speaking the truth to power." ${ }^{35}$

Ironically, the Gezi protests enabled young Turkish Muslims to redefine the Islamist project as a quest for justice for the Turkish downtrodden (e.g., the Kurds, the homeless, abused women and street children, and subcontract workers) and to fight injustice even when it comes from a religiously oriented government. What Özdenören calls false consciousness seems to be a re-enactment of the Medina model of Imam Hussain, Abdullah ibn Zubayr, and others. His political solutions, on the other hand, would create a dangerous moral vacuum for Muslims acting on the basis of naked Muslim interests when Islamic systems are not present. It is at this very moment that the contrast between the JDP's religious conservative ideology, which caters to the "Muslimist" goals based on Mu'awiyah's vision, and Islamism as an ethico-political ideal is the clearest.

Six months after the Gezi Park protests, Erdoğan's top-down Islamization policies remain in full force amidst serious reports of corruption, nepotism, exploitation, and sexual harassment, ${ }^{36}$ and continue to polarize the country. 
During these protests, everybody's identities have become far more transparent, even though the whole country has perhaps also become more polarized than ever. Yet the main cleavage is now defined by one's support of or opposition to Erdoğan's personage himself. It is hard to argue that the democratizing reforms have ceased in Turkey, especially after the policies to make Kurds and religious constituencies full citizens have recently made headlines in Turkey. But Erdoğan's concentration of power also continues to expand, coopting or forestalling any potential political opponents. It is hard to guess which path the country has taken. Nonetheless, it still remains a critical task to preserve one's ability to defend one's own convictions and speak truth to power by any means necessary.

\section{Endnotes}

1. BBC News Europe, "Four Turkey MPs wear headscarves in parliament," October 31, 2013, http://www.bbc.co.uk/news/world-europe-24761548 (accessed November 22, 2013).

2. See, for instance, Pen America, "Writer and Academic Ragip Zarakolu Arrested with Professor Büşra Ersanli," November 1, 2011, http://worldvoices.pen.org/ rapid-action/2011/11/01/writer-and-academic-ragp-zarakolu-arrested-professorb\%C3\%BCra-ersanl-0 (accessed November 22, 2013). Following her arrest, Ersanlı was detained for five months before being formally charged with "leading an illegal organization." She was known for her support for Islamist victims of the February 28 Coup.

3. Hürriyet Daily News, "Turkish locals continue protest of Black Sea hydro plant," October 10, 2010, http://www.hurriyetdailynews.com/default.aspx?pageid= $438 \& \mathrm{n}=$ environmetalists-protest-hydro-plants-in-black-sea-2010-10-11 (accessed November 23, 2013).

4. Ali Akel, “Özür açıklanmaz, özür dilenir!” Yeni Şafak, May 25, 2012, http:// yenisafak.com.tr/yazarlar/aliakel/ozur-aciklanmaz-ozur-dilenir/32548 (accessed November 22, 2013).

5. Bianet, "May Day in Istanbul: 72 Detained, Scores Injured," May 2, 2013, http://www.bianet.org/english/labor/146303-may-day-in-istanbul-72-detainedscores-injured (accessed November 22, 2013); Emek ve Adalet, "1 Mayıs'ta İBB Önünde Müdahale,” May 4, 2013, http://www.emekveadalet.org/arsivler/ 8809 (accessed November 22, 2013).

6. NBCnews.com, "Istanbul locked down during May Day protests," May 1, 2013, http://worldnews.nbcnews.com/_news/2013/05/01/18002098-istanbul-lockeddown-during-may-day-protests (access date: November 22, 2013).

7. Constanze Letsch, "Turkey's historic Emek theatre facing final curtain," The Guardian, April 15, 2013, http://www.theguardian.com/world/2013/apr/15/ turkey-historic-emek-theatre-final-curtain (accessed November 22, 2013). 
8. Livewire, "A hospital in Amnesty's office," June 14, 2013, http://livewire. amnesty.org/2013/06/14/a-hospital-in-amnestys-office/ (accessed November 22, 2013).

9. Hürriyet Daily News, "Death toll rises to five in Gezi protests as 19-year-old dies in Eskişehir," July 10, 2013, http://www.hurriyetdailynews.com/death-tollrises-to-five-in-gezi-protests-as-19-year-old-dies-in-eskisehir.aspx?PageID= $238 \&$ NID $=50408 \&$ NewsCatID $=341$ (accessed November 22, 2013).

10. Wikipedia, “2013 protests in Turkey," http://en.wikipedia.org/wiki/2013 protests_in_Turkey (accessed November 22, 2013).

11. Suzan Fraser and Nebi Qena, "\#OccupyGezi Protests: Prime Minister Recep Tayyip Erdogan Dismisses Turkey Demonstrators As Fringe," Huffington Post, June 2, 2013, http://www.huffingtonpost.com/2013/06/02/occupygezi-protetstserdogan-turkey_n_3375050.html (accessed November 22, 2013).

12. Orhan Kemal Cengiz, "Welcome to Post-Gezi Turkey" September 5, 2013, http://www.al-monitor.com/pulse/originals/2013/09/turkey-gezi-park-protestsquashed-democracy-polarized.html (accessed November 22, 2013).

13. Haber10, a once-radical Islamist website, posted an unsigned "special report" in which some political scientists and sociologists purportedly undertook to profile the Gezi protestors. Without grounding this on any empirical evidence, it alleged that their dominant profile was as follows: they are antagonistic toward the Kurds' demands, against hijabi women's participation the social life, worried about the public expression of religion, show a "statistically" very low interest in religious visibility and religious rituals, believe that the military should be influential in political life and consider a military coup as the final solution, and generally come from a tradition that supported the February 28 coup. Haber10, "İşte Taksim göstericilerinin profili," June 6, 2013, http://www.haber10.com/ haber/379239/\#.Uo-0fxJQiSo (accessed November 22, 2013). This report was then quoted by the pro-government Star newspaper, even though its "findings" could not be backed up by other empirical surveys. See for instance, KONDA's survey conducted on June 6-7, 2013, based on 4,411 respondents. Bianet, "94 Percent of Gezi Resisters Participate Individually, Poll Says," June 13, 2013, http://www.bianet.org/english/youth/147543-94-percent-of-gezi-resistersparticipate-individually-poll-says (accessed November 23, 2013).

14. Kemal Kirişçi, "Turkey Protests: Are the Youth at Gezi Park a New Actor in Turkish Democracy?" Brookings, June 13, 2013, http://www.brookings.edu/ blogs/up-front/posts/2013/06/13-turkey-protests-gezi-park-democracy-kirisci (accessed June 22, 2013).

15. This was the headline of Yeni Safak on June 15, 2013: "Operation Code Name Istanbul Riot." The article claimed: "While the external links of the Gezi incidents were investigated, the most active Israeli institute in Washington, DC, American Enterprise Institute was found to discuss a possible Istanbul riot in February with the American neo-cons. The "tahrir"-ization of the Taksim Square was debated in this simulation, where six Turkish citizens were also present." 
Yeni Şafak, "Kod adı İstanbul isyanı," http://yenisafak.com.tr/gundemhaber/kod-adi-istanbul-isyani-16.06.2013-533074. The renowned columnist Fehmi Koru, a one-time chief columnist of Yeni Şafak, confessed a month and a half later that this report was fabricated. See Taha Kıvanç, "Mısır'da olanları anlatıyorum ama tuzağa düşmeden..." Star, August 2, 2013, http://haber. stargazete.com/yazar/misirda-olanlari-anlatiyorum-ama-tuzaga-dusmeden/yazi778140 (accessed November 22, 2013).

16. Hüseyin Özay, “Gezi'nin finansörü 'Ayşe Teyze' çıktı” Taraf, November 21, 2013, http://www.taraf.com.tr/haber/gezi-nin-finansoru-ayse-teyze-cikti.htm (accessed November 22, 2013).

17. Abdulkadir Selvi, “Başbakan'ın sözünü ettiği gelin,” Yeni Şafak, June 12, 2013, http://yenisafak.com.tr/yazarlar/abdulkadirselvi/basbakanin-sozunu-ettigigelin/38114 (accessed November 22, 2013); Elif Çakır, "Genç Anne Z.D.'ye Yapılan Şiddetin Delili nerde?" Star, June 16, 2013, http://haber.stargazete.com/ yazar/genc-anne-zdye-yapilan-siddetin-delili-nerde/yazi-762937 (accessed November 22, 2013).

18. Radikal, "Dolmabahçe Camisi'nin imam ve müezzini, Beyoğlu'nun müftüsü gitti," September 21, 2013, http://www.radikal.com.tr/turkiye/dolmabahce camisinin_imam_ve_muezzini_beyoglunun_muftusu_gitti-1151887 (accessed November 22, 2013).

19. "Kadına Şiddete Karşı Müslümanlar İnisiyatifi: Başörtüsüne Saldırıyı Siyasi Malzemeye Dönüştürmek Ahlaksızlıktır" [Muslims against Violence against Women Initiative: It is Immoral to Turn the Attack against Hijab into a Political Instrument], http://www.baskahaber.org/2013/06/kadna-siddete-kars-muslumanlar.html (accessed November 22, 2013).

20. "Labor and Justice Coalition Declaration on Taksim Gezi Park Protests," June 22, 2013, http://www.jadaliyya.com/pages/index/12374/labor-and-justicecoalition-declaration-on-taksim- (accessed November 22, 2013).

21. Haber10, "İşte oligarşiye destek çıkan İslamcılar," June 20, 2013, http://www. haber10.com/haber/381226/\#.Uo59_hJQiSo (accessed November 22, 2013).

22. Enver Gülşen, "Steril Solculuk, Steril Demokratlık, Steril Müslümanlık," http:// envergulsen.wordpress.com/2013/06/17/steril-solculuk-steril-demokratlik-sterilmuslumanlik/ (accessed November 22, 2013).

23. Rasim Özdenören, "İlginç bir yanlış bilinç örneği," Yeni Şafak, June 23, 2013, http://yenisafak.com.tr/yazarlar/RasimOzdenoren/ilginc-bir-yanlis-bilinc-ornegi/ 38275; Rasim Özdenören, “İlginç bir yanlış bilinç örneği (2)," Yeni Şafak, June 27, 2013, http://yenisafak.com.tr/yazarlar/RasimOzdenoren/ilginc-bir-yanlisbilinc-ornegi-2/38336 (accessed November 22, 2013).

24. Akif Emre, “'İslamcıllk Yaptık da Ne Oldu?," Yeni Şafak, April 17, 2001, http:// yenisafak.com.tr/arsiv/2001/nisan/17/aemre.html (accessed November 22, 2013).

25. Hürriyet, "Siyasi İslam Yol Ayrımında [Political Islam Is at the Crossroads]," February 8, 2000, http://webarsiv.hurriyet.com.tr/2000/02/08/179069.asp (accessed May 13, 2013). 
26. Asef Bayat, "The Coming of a Post-Islamist Society," Critique: Journal for Critical Studies of the Middle East 5, no. 9 (1996). On page 45, he defines postIslamism as "a condition where, following a phase of experimentation, the appeal, energy, symbols, and sources of legitimacy of Islamism gets exhausted, even among its once-ardent supporters."

27. Asef Bayat, Making Islam Democratic: Social Movements and the Post-Islamist Turn (Stanford, CA: Stanford University Press, 2007), 19.

28. Steven A. Cook, "Turkey: Hello, I Must Be Going," Council on Foreign Relations, November 4, 2013, http://blogs.cfr.org/cook/2013/11/04/turkey-hello-imust-be-going/\#cid=soc-twitter-at-blogs-turkey_hello_i_must_be_going-110413 (accessed November 22, 2013).

29. For some representative works that draw a distinction between Islamism and Muslimism, see, Neslihan Cevik, "The Theological Roots of Liberalism in Turkey: 'Muslimism' from Islamic Fashion to Foreign Policy," Hedgehog Review 13, no. 2 (summer 2011); Akif Emre, "'Müslümancillk' ya da klan siyaseti," Yeni Şafak, August 26, 2008, http://yenisafak.com.tr/yazarlar/?i=12487\&y=AkifEmre (accessed November 23, 2013).

30. Abdelwahab El-Affendi, Who Needs an Islamic State? 2d ed. (London: Malaysia Think Tank, 2008), 66.

31. Ibid., 171.

32. Asef Bayat, Making Islam Democratic. He continues, on page 6: "It was the Muslim middle-class way of saying no to what they considered their excluders-their national elites, secular governments, and those governments' Western allies."

33. It is significant that for Qutb, even offensive warfare is articulated on ethical grounds, i.e., removing the obstacles posed by tyrants against the freedom of religion.

34. "Savaşa ve İşgale Hayır Platformu," http://www.musluman.o-f.com/diger/platform. htm (accessed November 22, 2013).

35. Hamid Dabashi, Islamic Liberation Theology: Resisting the Empire (London: Routledge, 2008), 214.

36. A recent example involves the director of education for Istanbul's Fatih District, famous for its religiousity, who has just been convicted of sexually harassing two female civil servants. His file was dismissed twice by the Education Ministry's inspectors before the victims insisted on going to court and getting the conviction. The ministry has still not removed him from his position. Under a "religious" government that has supported moral policing for the youth, the frequency of such covered-up sexual harassment cases is striking. See Umay Aktaş Salman, "Tacizden ceza alan Milli Eğitim Müdürü 'görevinin' başında" [The National Education Director, who got jail term for harassment is back to work]," Radikal, November 20,2013, http://www.radikal.com.tr/turkiye/tacizden_ceza alan_milli_egitim_muduru_gorevinin_basinda-1161921 (accessed November 23, 2013). 